\title{
A new Campanula (Campanulaceae) from east Anatolia, Turkey
}

\author{
Ali Kandemir \\ A. Kandemir (akandemir@gmail.com), Dept of Science Education, Erzincan, Faculty of Erzincan Education, TR-24030, Erzincan Univ., \\ Turkey.
}

Campanula demirsoyi A. Kandemir (Campanulaceae) is described and illusturated from a localised area of Erzincan province. It is closely allied to $C$. hedgei Davis and C. coriacea Davis. Diagnostic morphological characters are discussed and compared with those of related taxa.

The genus Campanula L. comprises ca 300 species widely distributed in temperate areas of the Northern Hemisphere. It includes annual and perennial plants (Saez and Aldasoro 2003). Two-thirds of all Campanula grow in the Mediterranean, the Black Sea region and west and central Asia. It extends as far north as the Eurasiatic-Artic regions and Japan, as well as in North America, where 22 indigenous taxa have been recorded. Some species are found in eastern Africa and in the southern Sahara mountains as far as Morocco. The perennial species occupy either regions of very large geographical distribution, or are confined in restricted ranges as an important element (Contandriopoulous 1984).

The genus Campanula as represented in Turkey is divided into six subgenera: Campanula, Megalocalyx, Roucela, Brachycodonia, Sicyodon and Rapunculus (Damboldt 1976). Some plant samples belonging to subgenus Campanula were collected from the Munzur Mountains (B7 ErzincanTurkey) during the flowering period by the author. The range of the Munzur mountains is one of the centres for endemic plants, located on the Anatolian diagonal and many endemic Campanula species grow in this interesting area (Davis 1962, Huber-Horath 1963, Ekim and Güner 1986, 2000, Yildırıml 1995). The samples were compared to many specimens of supposedly related species in the Edinburgh Herbarium (E). The studies showed that the new samples were representatives of a new species related to $C$. hedgei P. H. Davis and C. coriacea P. H. Davis.

\section{Campanula demirsoyi Kandemir sp. nov. (Fig. 1)}

C. hedgei P. H. Davis et C. coriaceae P. H. Davis affinis, sed a $C$. hedgei caule infra pubescenti vel retrorsum hirsuto, supra glabro (non omnino pubescenti vel retrorsumhirsuto), calyce glabro, dentibus costatis (non hispidulo dentibus costatis), corolla cylindraceo-campanulata, 10-13 $\times$ 5-7 mm, glabra (non anguste cylinraceo-campanulata, 13-20 $\times 10-12 \mathrm{~mm}$ extus et interdum intus pubescenti) distincta; a C. coriacea caule infra pubescenti vel infra retrorsum hirsuto, supra glabro (non omnino pilis crispatis tecto), calycis dentibus costatis (non ecostatis), corolla cylindraceo-campanulata, 10-13 ×5-7 $\mathrm{mm}$, glabra (non late infundibulari-campanulata, 9-12 ×8-12 $\mathrm{mm}$, extus hispida), stylo incluso (non exserto) differt.

Type: Turkey. B7 Erzincan: Munzur mountains, along Mercan river, $1968 \mathrm{~m}$, limestone crevices $39^{\circ} 31^{\prime} \mathrm{N}$, $39^{\circ} 35^{\prime} \mathrm{E}^{\prime}$, 04.VII.2005, A. Kandemir 6992 (Holotype: GAZI, Isotype: ANK).

Perennial; stems 1-6 from a woody caudex, branched, ascending to erect, firm, $18-35 \mathrm{~cm}$, pubescent or retrorsehirsute below (hairs ca $0.4 \mathrm{~mm}$ ) glabrous above, cauline leaves firm, obovate to oblanceolate with narrowly winged petiole, $1-6 \times 0.5-1 \mathrm{~cm}$, strigose, obscurely dentate to irregularly serrate; upper cauline leaves similar, sessile or shortly pedicellate, attenuate at base. Flowers erect, sessile to shortly pedicellate (ca $0.5 \mathrm{~mm}$ ), axillary in a lax spicate or terminal inflorescence, solitary with floral leaves; bracts shorter than calyx, hispid at least at apex. Ovary shortly obconical, glabrous, $2.5 \mathrm{~mm}$. Calyx glabrous, lobes lanceolate 3-5 mm, thickened on the midrib and along the edges, with retrosely strigose margins, at least near the apex, appendages between the adjacent lobes, small, ca $0.5 \mathrm{~mm}$. Corolla deep blue, cylindrical to campanulate, $10-13 \mathrm{~mm}$ long, 5-7 mm wide, divided to $1 / 4$, glabrous, lobes 3-4 $\mathrm{mm}$, ovate, triangular. Stamen $1.5-2.5 \mathrm{~mm}$; filiform part of filament $0.5-0.9 \mathrm{~mm}$; base oblong-elliptic, $1-1.3 \times 1.4$ $1.5 \mathrm{~mm}$, ciliate at base. Anthers $4-5 \mathrm{~mm}$, shorter than 


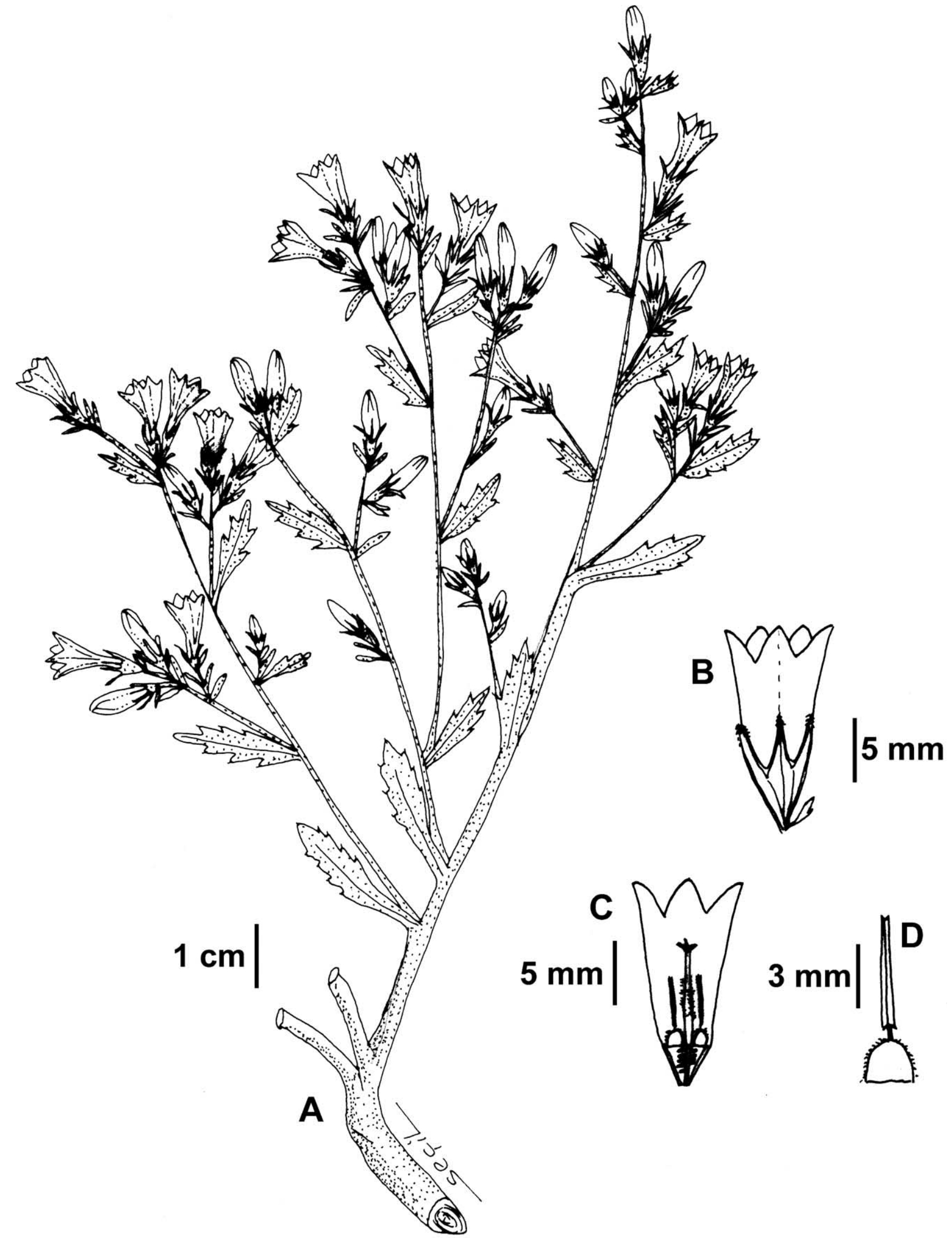

Fig. 1. Campanula demirsoyi. (A) habit (holotype), (B) flower, (C) dissection of a flower, (D) stamen and details of stamen base. 


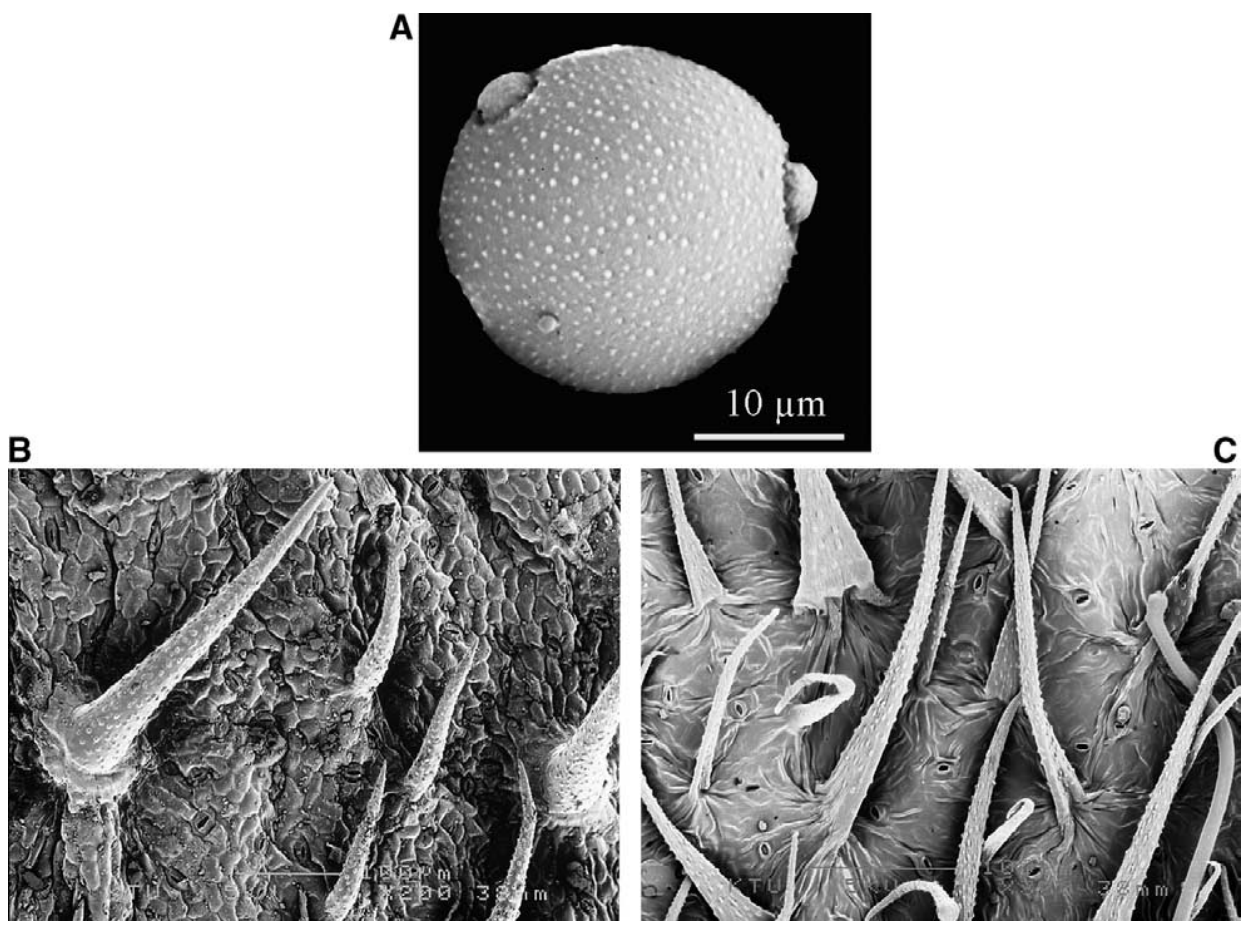

Fig. 2. Scanning electron micrographs. (A) pollen of $C$. demirsoyi $(3000 \times)$, (B) leaf surface of $C$. demirsoyi $(300 \times)$, $(\mathrm{C})$ leaf surface of C. hedgei $(300 \times)$.

style; pollen grain monad, shape sphaeroidal, equatorial outline circular, 3-porate, ornamentation microechinatemicroreticulate, $20-24 \mu \mathrm{m}$ in diameter. Styles $5.2-9 \mathrm{~mm}$, hairy below, glabrous above. Stigma 3, short, included. Capsule unknown.

\section{Ecology and conservation status}

The plant grows in limestone crevices at $1968 \mathrm{~m}$ altitude with $C$. hedgei. The specimens were collected from the Munzur mountains. Campanula demirsoyi is an endemic species and probably restricted to this area. However, the IUCN category of the new species is considered to be data deficent (DD) for the time being according to the IUCN red list categories (Pullin 2004). In order to suggest another IUCN category, more investigations are needed to clearly determine the distribution, population size and threats.

\section{Discussion}

Campanula demirsoyi A. Kandemir belongs to the section Rupestres Boiss.) Charadze of the subgenus Campanula (Damboldt 1978). It is very distinct from other species in the section. However, some of its features are similar to C. hedgei and C. coriacea.

Campanula demirsoyi and $C$. hedgei are sympatric in the Munzur mountains (Fig. 2) and C. demirsoyi is closer to $C$. hedgei than to $C$. coricea. Campanula hedgei has

Table 1. Diagnostic characteristics of Campanula demirsoyi and C. hedgei.

\begin{tabular}{|c|c|}
\hline Campanula demirsoyi & Campanula hedgei \\
\hline $\begin{array}{l}\text { Stem pubescent or retrorse-hisute below (hairs ca } 0.3 \mathrm{~mm} \text { ), } \\
\text { glabrous above, } 5-22 \mathrm{~cm}\end{array}$ & $\begin{array}{l}\text { Stem pubescent or retrorse hirsute throughout (hairs } \\
\text { ca } 0.5 \mathrm{~mm}), 18-35 \mathrm{~cm}\end{array}$ \\
\hline $\begin{array}{l}\text { Epidermal cell of irregular shape (tetragonal to isodiametric), } \\
\text { with straight anticlinal walls, smooth periclinal walls and multicellular } \\
\text { trichomes showing a big micropapillate secondary sculpture }\end{array}$ & $\begin{array}{l}\text { Epidermal cell shape not distinct and several unicellelar } \\
\text { trichomes with small micropapillate secondary sculpture }\end{array}$ \\
\hline Stem leaves obovate or oblanceolate & Stem leaves brodly ovate or orbicular \\
\hline Calyx glabrous, teeth thick at margins & Calyx pubescent to hispidulous, teeth not thick \\
\hline Corolla cylindirical to campanulate, $10-13 \times 5-7 \mathrm{~mm}$, glabrous & $\begin{array}{l}\text { Corolla narrowly cylindirical-campanulate, } 13-20 \times 10-12 \mathrm{~mm} \text {, } \\
\text { pubescent outside, glabrous or hairy inside }\end{array}$ \\
\hline Ovary glabrous, midrib thick & Ovary pubescent hispidulous, midrib not thick \\
\hline Anther $4-5 \mathrm{~mm}$ & Anther $4.5-6 \mathrm{~mm}$ \\
\hline Filiform part of filament linear, base oblong-elliptic & Filiform part of filament lanceolate, base oblong \\
\hline
\end{tabular}




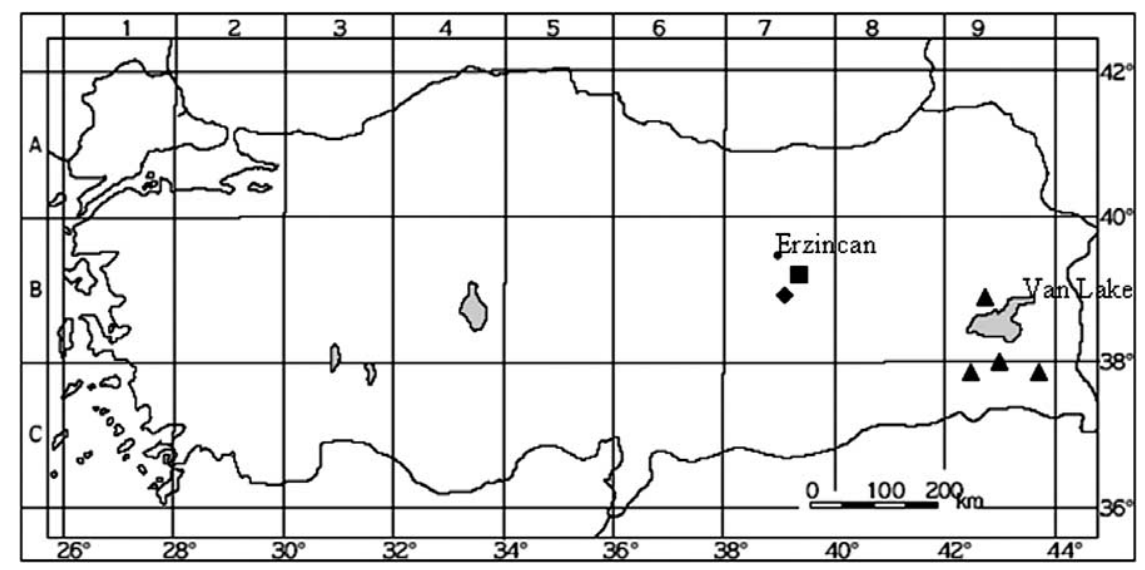

Fig. 3. The distribution of Campanula demirsoyi A. Kandemir sp. nov.

, C. hedgei Davis and C. coriacea Davis ( $\mathbf{\Lambda}$ ) in Turkey.

retorse-hirsute stems, broadly ovate or orbicular cauline leaves, hispidulous ovary, corolla pubescent outside and hairy inside. Triangular filiform part of the filament is different from $C$. demirsoyi which has stem pubescent or retrorse-hirsute below, almost glabrous above, leaves obovate or oblanceolate, ovary and corolla glabrous, distinctly thickened and edge of calyx teeth and midrib of calyx linear filiform part of filament (Table 1). According to the flora of Turkey, the corolla of $C$. hedgei is glabrous inside (Damboldt 1978). The corolla is hairy inside in most examined specimens belonging to $C$. hedgei. In addition, other morphological characteristics like leaf surfaces were compared by scanning electron microscopy (SEM). The epidermal cells are irregular in shape (tetragonal to isodiametric) and has straight anticlinal walls, smooth periclinal walls and multicellelar trichomes showing a big micropapillate secondary sculpture in $C$. demirsoyi. The epidermal cell shape is not distinct and has several unicellelar trichomes with small micropapillate secondary sculpture in C. hedgei (Fig. 2).

Campanula coriacea is the other species that closely resembles $C$. demirsoyi. It inhabits the Van lake area far from the Munzur mountains (Fig. 3). Campanula coriacea is less similar to the species described here than it is to C. hedgei. So, a more detailed comparison was not performed between $C$. coriacea and $C$. demirsoyi. However, some floral differences were noted and are emphasized here. C. coriacea has a brodly campanulate corolla, divided into halves, the lobes are barbate inside, the tube is hispid outside and the style is exerted whereas $C$. demirsoyi has narrowly cylindrical to campanulate corolla, divided to $1 / 4$, glabrous with the style included.

The range of the Munzur mountains is one of the centres for endemic plants in Turkey and is located on the Anatolian diagonal (Ekim et al. 2000). The concept of the diagonal was first proposed by P. H. Davis (Davis 1971). Thirty-three percent of the species growing in Turkey are found along the diagonal, and five percent are more or less restricted to it (Ekim and Güner 1986). Seventeen Campanula taxa grow in the Munzur mountains, eight of which are endemic, and five endemic species grow in this area only (Damboldt 1978, Yildırıml 1995). The range of the Munzur mountains is an important area for the diversity of the genus Campanula.

\section{Etymology}

The new species was named in honour of Prof. Dr Ali Demirsoy (Biology Dept, Sci. Fac. of Hacettepe Univ. in Turkey).

\section{Examined specimens of related species}

Campanula coriacea; Turkey. B9 Bitlis: Adilcevaz, in limeston crevices, $1900 \mathrm{~m}, 25$ Aug 1954, Davis \& O. Polunin, D. 24608, Holotype, Inter cilicio-kurdicum, 1859 (syn C. radula) (E), Turkey. Van: South foothills of Artos Dağı, West of Van, Çatak road, 2000 m, 8 May 1986, J. C. Arachibald 8315 (E), Turkey. Van: Başkale, İspiriz Daği, 2600 m, 31 Jul 1954, Davis \& O. Polunin, D.23622 (E), Turkey. Van: 28 Jul 1954, Davis \& O.Polunin, D.23273 (E), Turkey. Van: River Valley, West of Yukari Narlica to Bahçesaray, 2200 m, 5 Aug 1986, J. C. Arachibald 8010 (E). Turkey. Van: old town of Van, $1800 \mathrm{~m}, 1$ Sep 1956, McNeill 721 (E), Turkey. Van: Gevaş, 1800 m, 13 Jul 1954, Davis \& O. Polunin, D. 22671 (E), Turkey. Van: HavasorHoşhap, 30 Jul 1954, Davis \& O. Polunin, D 23312 (E). C. hedgei Davis: Turkey. Tunceli, Munzur Dağ above Ovacik, 2400 m, 18 Jul 1957, Davis \& Hedge D. 31358 Holotype (E), Turkey. Tunceli, Munzur Daği above Ovacik, $2400 \mathrm{~m}$, 19 Jul 1957, Davis \& Hedge D. 31315 (E), Turkey. B7 Erzincan: Keşiş Daği, above Cimin, 2700-2900 m, 27 Jul 1957, Davis \& Hedge D. 31634, Turkey. B7 Erzincan: Keşiş Dağlari prov. Çamlik $39^{\circ} 45^{\prime} \mathrm{N}, 39^{\circ} 44^{\prime} \mathrm{E}, 2440 \mathrm{~m}, 15 \mathrm{Jul}$ 2004, Kandemir 6449 (EEFH).

Acknowledgements - The plant specimens were collected in BAP 2005-131 Project, supported by Atatürk Univ. Sci. Res. Fund. In addition, I wish to thank to Dr W. M. M. Eddie, from Edinburgh Univ., for his comments, Prof. Dr Hayri Duman for writing the Latin description, and Dr Secil Soydan for the illustration.

\section{References}

Contandriopoulos, J. 1984. Differentiation and evolution of the genus Campanula in the mediterranean region. - In: William, F. G (ed.), Plant biosystematics. Academic Press, pp. 140-175. 
Damboldt, J. 1976. Materials for a flora of Turkey XXXII: Campanulaceae. Notes. - R. Bot. Gard. Edinburgh. 35: 4052.

Damboldt, J. 1978. Campanula L. - In: Davis, P. H. (ed.), Flora of Turkey and east Aegean Islands. Edinburgh Univ. Press, 6: $2-64$.

Davis, P. H. 1962. Materials for a flora of Turkey: VI. Notes. - R. Bot. Gard. Edinburgh. 24: 29-33.

Davis P. H. 1971. Distribution patterns in Anatolia with particular reference to endemisim. - In: Davis, P. H. (ed.), Plant life of south-west Asia. - Bot. Soc. Edinburgh, pp. $15-27$.

Ekim, T. et al. 2000. Turkish plants red data book. - Dogal Hayatı Koruma Dernegi, Ankara.
Ekim, T. and Güner, A. 1986. The Anatolian diagonal: fact or fiction? - Proc. Soc. Edinburgh. 89B: 69-77.

Huber-Horath, A. 1963. Novitiae florae Anatolicae VI. - Bauhinia 2: 29-33.

Pullin, A. S. 2004. Conservation biology. - Cambridge Univ. Press, p. 207.

Saez, L. and Aldasoro, J. J. 2003. A taxonomic revision of Campanula L. subgenus Sicyocodon (Feer) Damboldt and subgenus Megalocalyx Damboldt (Campanulaceae). - Bot. J. Linn. Soc. 141: 215-241.

Yıldırmlı, Ş. 1995. Flora of Munzur. - Ot Sistematik Botanik 2: $1-78$. 